\title{
Developments In Stem Educators' Preparedness For English Language Learners In The United States
}

Keith R. Besterman, Virginia Tech, USA

Jeremy Ernst, Embry-Riddle Aeronautical University, USA

Thomas O. Williams, Virginia Tech, USA

\begin{abstract}
In the United States, the population of students classified as English Language Learners (ELLs) in K-12 education has increased in recent decades. As a result, teachers outside of specialized linguistic courses have needed to adapt their instruction to better meet the needs of these students. This exploratory study investigates potential indicators of Science, Technology, Engineering, and Mathematics (STEM) teachers' preparedness to work with ELLs, in comparison with the rates of ELLs in STEM courses.

Data for this study were obtained from the national restricted-access datasets of the 2007-2008 and 2011-2012 School and Staffing Survey (SASS) Teacher Questionnaire (TQ). STEM teachers' participation in ELL-focused professional development activities, credentialing related to ELLs, and ELL populations in STEM teachers' courses were analyzed to quantify changes in these measures over time and among the STEM disciplines. Regional analysis of STEM teacher populations and ELL populations in STEM classes was also conducted to examine how these factors differed across the United States.

Analyses of these data indicated increases in the percentage of STEM teachers who have ELLs in their service loads and in the average number of ELLs in teacher service loads; these trends were present in all U.S. regions and in all STEM disciplines. However, the total number of STEM teachers who participated in ELL-focused professional development activities increased only slightly over the four-year span. To effectively teach the growing ELL student population, STEM teachers must develop the skills and approaches necessary to educate and engage these students.
\end{abstract}

Keywords: STEM Education; Schools and Staffing Survey Teacher Questionnaire; English Language Learners; AtRisk Learners

\section{INTRODUCTION}

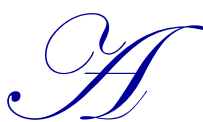

cross the United States English Language Learners (ELLs) constitute nine percent of all public school students and are enrolled in three out of every four public schools (U.S. DOE \& U.S. DOJ, 2015). Furthermore, children of immigrants, half of whom do not speak English fluently and are thus labeled English learners, are the fastest-growing student population in U.S. schools (Calderón, Slavin, \& Sánchez, 2011). Growth projections of the ELL population speculate that by the 2030s the number of Language Minority (LM) students will constitute 40 percent of the school-age population (Thomas \& Collier, 2001). The rising numbers of students classified as ELLs in the K-12 education system has amplified national attention on helping teachers support the academic success of language minority students (Molle, 2013; NCES, 2016). Despite the increased focus on this group of learners, teachers are not yet well prepared to meet the needs of this emergent learner population (García, Arias, Harris Murray, \& Serna, 2010). This population is of particular concern since students who grew up in English language isolated communities, or do not speak English because they are from a country whose primary language is not English, are at increased jeopardy of struggling academically (Honigsfeld \& Dunn, 2009). Research not only indicates that the ELL population is growing, but also that across the United States areas that have not traditionally 
served large ELL populations are now experiencing sizable increases in their ELL student body (Cheung \& Slavin, 2012; National Clearinghouse on English Language Acquisition, 2010; Pereira \& de Oliveira, 2015).

The scale of the ELL population within a state varies immensely across the United States. Data from the National Center for Educational Statistics (2015) found that California had the highest percentage of ELL students with 22.7 percent of the public school population being classified as ELL, and West Virginia had the lowest percentage with 0.7 percent of the public school population being classified as ELL (p.1). This uneven distribution of the ELLs across the U.S. makes addressing the needs of this population of learners from a federal level complex. Calderón et al. (2011) stated,

Although the federal government requires districts to provide services to English learners, it offers states no policies to follow in identifying, assessing, placing, or instructing them. States, therefore, vary widely in the policies and practices by which they identify and assess English learners for placing within and exiting from instructional programs (p.104).

As such, issues related to meeting the needs of ELLs are often contextualized at a state level. At this level it is commonplace for a simplified version of the federal definition or a specific definition that is tailored to the needs of the community to be used (Hopstock, Bucaro, Fleischman, Zehler, \& Eu, 1993; Zehler, et al., 2003).

Content-based language instruction is often presented to ELLs by language specialist, including ESL (English as a Second Language) and ESOL (English for Speakers of Other Languages) teachers; however, the success of this approach is limited by the extent of ESL and ESOL teachers' content knowledge in other academic disciplines (Lee, Quinn, \& Valdés, 2013). As the population of ELLs grows, general education teachers will have to augment their content knowledge and pedagogy with knowledge and skills specific to ELLs to ensure that all of their students are able to reach the grade level standards (Samson \& Collins, 2012). Calderón et al. (2011) suggest "To help English learners catch up when they fall short in core knowledge, all disciplines must practice vocabulary knowledge, reading, and writing instruction" (p.111). The need for all teachers and policymakers to familiarize themselves with the unique demands of educating ELLs is garnering growing attention in educational literature (Liu, Thurlow, Erickson, Spicuzza, \& Heinze, 1997). Unfortunately, throughout the field of education, reforms to meet the needs of ELLs are trailing behind the actual growth of ELLs in classrooms (August, Shanahan, \& Escamilla, 2009; Ballantyne, Sanderman, \& Levy, 2007; Menken \& Antunez, 2001).

Even though general education teachers are increasingly being asked to adapt instruction for ELLs, many educators lack the institutional support and specific expertise needed to address the complex educational needs of ELLs (Lee, 2005). Educational literature supports the notion that the quality of instruction a student receives is heavily dependent on the abilities of their educator and that expectations for student advancement should be rooted in support for teacher improvement (Calderón et al., 2011; Cheung \& Slavin, 2012). Teacher training, education, and certification present opportunities for improvement of teaching practices, and in particular could be utilized to prepare educators to better serve their ELL students (Daniel, 2014; Darling-Hammond, 1996; Molle, 2013; Nadelson, Seifert, Moll, \& Coats, 2012). In a review of literature related to teaching academic English to ELLs, DiCerbo, Anstrom, Baker, and Rivera (2014) noted "The literature reviewed suggests that high-quality professional development can provide meaningful learning experiences for teachers on academic English within subject area contexts" (p.472). Building up the capabilities of mainstream educators to work more effectively with ELLs is an essential component of a successful education system.

Since broadly introduced in 2001 by the National Science Foundation (NSF), the term STEM education has gained mainstream popularity (Marrero, Gunning, \& Germain-Williams, 2014; Sanders, 2009). STEM education reforms offer potential benefits for all students and overlap with proposed best-practices of ELL focused reforms. However, the achievement gap between ELLs and their native-speaking peers in STEM subjects further highlights the missed educational opportunities ELLs face when mainstream teachers are not prepared to meet the unique needs of ELLs (DelliCarpini \& Alonso, 2014). Educational methodologies that have an emphasis on STEM often utilize ProjectBased Learning (PBL) opportunities to contextualize course content and build meaningful understandings through critical and analytical thinking, collaboration with peers, self-directed learning, and real-world problem solving (Capraro, Capraro, \& Morgan, 2013, p.2). The use of tactile activities that employ hands-on learning experiences and 
manipulatives have also been reported as a core feature of STEM education PBL activities as well as an applicable approach to learning for ELLs (Honigsfeld, \& Dunn, 2009, p.221). Furthermore, the utilization of collaborative groups is a notable feature of STEM education (Breiner, Harkness, Johnson, \& Koehler, 2012) as well as a widely supported instructional methodology for ELLs (August, \& Shanahan, 2010; Calderón et al., 2011; Fillmore, 2014; Krashen, 1981 ; Pereira \& de Oliveira, 2015). STEM disciplines are promoted as strategic components of a $21^{\text {st }}$ century education to prepare students for a knowledge-based workforce (Bybee, 2010; Marrero et al., 2014). As such, it is critically important that STEM educators are prepared to meet the learning needs of ELLs within these disciplines (Lee, 2005; Janzen, 2008).

The rapid growth of the ELL population continues to garner national attention to this group of learners (Calderón et al., 2011). Additionally, the quality of the educational environment ELLs find when entering the K-12 system in the United States is directly impacted by teachers' level of preparedness to meet the needs of this population (Calderón et al., 2011; Cheung, \& Slavin, 2012). Barriers to academic success for ELLs would contribute to a negative "context of reception" (Portes, \& Rumbaut, 2001; Schwartz, et al., 2014), particularly for ELL students who are children of immigrants. Currently, students categorized as ELLs are at risk of struggling academically (Honigsfeld, \& Dunn, 2009), and the preparedness of their educators contributes to their potential for success (DelliCarpini \& Alonso, 2014). Failing to meet the needs of diverse learners in the K-12 system can have a lasting effect on their perceptions of opportunities within and beyond school (Portes, \& Böröcz, 1989; Portes, \& Rumbaut, 2014). There is a continued need for research on teacher credentialing related to meeting the needs of English Language Learners at a nationallevel to inform policy and practices (DelliCarpini \& Alonso, 2014; Lee, 2005).

\section{RESEARCH QUESTIONS}

This exploratory investigation is guided by three core research questions related to changes in both the population of ELLs in STEM courses and the credentialing of STEM educators pertaining to ELLs.

1) To what extent has the number of ELLs changed over time across the STEM disciplines nationally?

a) Have STEM teachers' service-loads of ELLs changed over time?

2) To what extent have STEM educators' credentialing related to ELLs changed over time nationally?

a) To what extent has the percentage of STEM teachers that hold Language related credentials changed over time?

b) To what extent has the percentage of STEM teachers that hold Culture related credentials changed over time?

c) To what extent has the amount of ELL focused professional development that STEM teachers participate in yearly changed over time?

3) To what extent have STEM teachers' service-loads of ELLs changed over time in the STEM disciplines within and across regions?

a) Have STEM teachers' service-loads of ELLs changed over time regionally?

These questions will be explored through variable isolation of data from the most recent and the second-most recent Schools and Staffing Survey (SASS) Teacher Questionnaires (TQ).

\section{METHODS}

\section{Instrumentation}

Data from the two most recently available Schools and Staffing Surveys (SASS) were employed in this study. The SASS consist of five complimentary questionnaires that make up the SASS: a School District Questionnaire, Principal Questionnaire, School Questionnaire, Teacher Questionnaire, and School Library and a Media Center Questionnaire. This investigation utilizes data solely from the Schools and Staffing Survey Teacher Questionnaire (SASS TQ). When describing the SASS, Tourkin et al. (2010) stated:

The Schools and Staffing Survey (SASS) is conducted by the National Center for Education Statistics (NCES) on behalf of the U.S. Department of Education in order to collect extensive data on American public and 
private elementary and secondary schools. SASS provides data on the characteristics and qualifications of teachers and principals, teacher hiring practices, professional development, class size, and other conditions in schools across the nation. The overall objective of SASS is to collect the information necessary for a comprehensive picture of elementary and secondary education in the United States. The SASS was designed to produce national, regional, and state estimates for public elementary and secondary schools and related components and is an excellent resource for analysis and reporting on elementary and secondary educational issues (p.1).

Data were utilized to examine STEM teachers' certifications related to ELLs, changes in STEM teachers' service-load of ELLs, and regional analysis of related changes over time using data from the 2007-2008 and 2011-2012 school years.

\section{Variables Analyzed}

Within the SASS TQ dataset, regional information is a derived variable created from the state-level information provided by participants. The regional categories are: Northeast (Connecticut, Maine, Massachusetts, New Hampshire, New Jersey, New York, Pennsylvania, Rhode Island, and Vermont), Midwest (Illinois, Indiana, Iowa, Kansas, Michigan, Minnesota, Missouri, Nebraska, North Dakota, Ohio, South Dakota, and Wisconsin), South (Alabama, Arkansas, Delaware, District of Columbia, Florida, Georgia, Kentucky, Louisiana, Maryland, Mississippi, North Carolina, Oklahoma, South Carolina, Tennessee, Texas, Virginia, and West Virginia), and West (Alaska, Arizona, California, Colorado, Hawaii, Idaho, Montana, Nevada, New Mexico, Oregon, Utah, Washington, and Wyoming) (Tourkin, et al., 2010, p.1020). The service load of ELLs a teacher serves will be measured by responses to Question 15:

Of all the students you teach at this school, how many are of limited-English Proficiency or are Englishlanguage learners (ELLs)? (Students of limited-English proficiency [LEP] or English-language learners [ELLs] are those whose native or dominant language is other than English and who have sufficient difficulty speaking, reading, writing, or understanding the English language as to deny them the opportunity to learn successfully in an English-speaking-only classroom.) (NCES, 2014, p.10)

Participation by teachers in ELL related professional development opportunities will be determined by responses to question 49a, "In the past 12 months, have you participated in any professional development on how to teach limitedEnglish proficient students or English-language learners (ELLs)?" (National Center for Educational Statistics, 2014, p.31). Beyond participation, the number of hours spent on professional development relating to ELLs will be determined by responses to question 49b, "In the past 12 months, how many hours did you spend on these activities?" (National Center for Educational Statistics, 2014, p.31). Responses regarding the number of hours spent participating in ELL specific professional development in the last year was measured by Question $49 \mathrm{~b}$ which is structured on a four-level ordinal scale from "8 hours or less", "9-16 hours", "17-23 hours", to "33 hours or more" (NCES, 2014, p.31).

For the purposes of this study teachers' degrees, graduate certificates, and state level certifications are represented in composite credential categories. Categories are separated by Linguistic and Cultural focus as well as separated through degrees or state-level certifications. Although the order of the questions in the SASS TQ change slightly between the 2007-2008 and 2011-2012 surveys the content of the questions remains the same and therefore comparisons between years can be made. Possession of specific degrees or state level certifications will be measured by responses to questions 25a, 25d, 25e, 25f, 27a, 27e, 28, 25g, 25h, 37a, 37b, 37d, 38a, 38b, 38c, 38d, and 38e of the 2011-2012 SASS TQ survey and the corresponding questions from the 2007-2008 dataset (NCES, 2014). These sections of questioning within the SASS TQ include the major field of study for bachelor's degrees, second majors, master's degrees, graduate certificates, doctorate or professional degrees, as well as the content area for primary as well as secondary state-level teaching certifications. Regarding participants' bachelor's degrees, second majors, master's degrees, graduate certificates, and doctorate or professional degrees they are asked to provide a major field of study that best describes the focus of the degree using the provided table of response codes. Similarly, for participants' statelevel certifications they are asked to indicate which response code best describes the content area that their certification allows them to teach in. Credentials specific to the scope of this investigation will be categorized as either Cultural 
Degrees, Cultural Certifications, Linguistic degrees, or Linguistic Certifications. Categorization into these groups is determined by response codes regarding the subject matter of the credential. The content codes for major field of study regarding degrees are also used for content area of state-level certification, thus the same response codes will be used by participants to indicate area of focus for degrees and state-level certifications. The categories of Cultural Degrees and Cultural Certifications represent response codes of 221 (Anthropology), 222 (Area or ethnic studies, excluding Native American Studies), 224 (Cultural studies), 231 (Native American Studies), or 229 (International Studies). The categories of Linguistic Degrees and Linguistic Certifications denote response codes of 160 (ESL or bilingual education: General), 161 (ESL or bilingual education: Spanish), 162 (ESL or bilingual education: Other), or 156 (Linguistics) (NCES, 2014, p.15). The response codes that are used to create the composite categories of Cultural credentials and Linguistic credentials are from a table of possible response codes included in the SASS TQ survey that allow for respondents to indicate the area of study a degree they possess is in or the area of study a particular state-level certification they possess allows them to teach in. The codes that comprise the categories of Cultural and Linguistic credentials were chosen from the complete list of possible response codes as those that best represented evidence of relevant knowledge to the concepts of either culture or linguistics. From all of the response codes included in the SASS TQ the codes representing Area or ethnic studies, Cultural studies, Native American Studies, Anthropology, and International Studies were chosen as the best representatives of credentialing related to Culture. To comprise the category of Linguistic credentials the response codes corresponding to ESL or bilingual education: General, ESL or bilingual education: Spanish, ESL or bilingual education: Other, and Linguistics were chosen as the most appropriate areas of focus.

\section{Participant Description}

The target population utilized in this study is K-12 educators within STEM disciplines. Within the context of this study the classification of STEM disciplines is separated into the categories of Science, Technology, and Mathematics. Participants are placed into one of these groups based on subject matter codes given in response to question 16 of the SASS TQ, "This school year, what is your MAIN teaching assignment field at THIS school?" (National Center for Educational Statistics, 2014b, p.10). Categorization as a Science teacher is determined by response codes of 210(Science, general), 211(Biology or life sciences), 212(Chemistry), 213(Earth Science), 215(Integrated science), 216(Physical sciences), or 217(Physics). Participants are categorized as Technology teachers if they responded with codes of 246 (Construction trades, engineering, or science technologies (including CADD and drafting), 247 (Manufacturing and precision production (electronics, metalwork, textiles, etc.), 250 (Communications and related technologies (including design graphics, or printing; not including computer science), or 255 (Industrial arts or technology education). Additionally, teachers will be categorized as Mathematics educators if they responded with the category code of 191 (Algebra I), 192 (Algebra II), 193 (Algebra III), 194 (Basic and general Mathematics), 195 (Business and applied math), 196 (Calculus and pre-calculus), 198 (Geometry), 199 (Pre-algebra), 200 (Statistics and probability), or 201 (Trigonometry). The category codes of 197 (Computer science) and 214 (Engineering) were intentionally not included in the aforementioned groupings since these codes are placed under the headings of Mathematics and Natural Sciences respectively within the SASS TQ but do not fit into the general understanding of what these headings represent.

\section{Analysis Methods}

This exploratory investigation utilized secondary analysis of the 2007-2008 and 2011-2012 SASS TQ restricted-use license datasets. A national profile of STEM teachers' credentials related to ELLs, regional differences in credentials, and changes over time in these categories was created and investigated using this data. In the utilization of the SASS dataset the National Center for Educational Statistics (NCES) and Institute for Educational Sciences (IES) require that all weighted $n$ 's are rounded to the nearest 10 to assure participant anonymity. Due to these required rounding adjustments the data included in tables might not add to the total $\mathrm{N}$ reported. When analyzing weighted data from the SASS TQ dataset, the National Center for Educational Statistics' (NCES) recommends that any figures that had a weighted response value of less than 50 are noted as not being stable. Therefore, weighted data that was found to be unstable is replaced with an asterisk in the reported tables. All data reported in this study are weighted. 


\section{RESULTS}

National data gathered from the 2007-2008 and 2011-2012 SASS TQ dataset regarding STEM teachers' professional development participation regarding ELLs, credentialing related to ELLs, and rates of interactions with ELLs are summarized in tables reflecting the changes between the years of reporting. Regional data was also gathered and reported to identify changes in the percentages of STEM teachers who reported having ELLs in their overall service load of students as well as changes in the mean number of ELLs teachers had in the years reported. The focus of this study is the changes that have occurred in the data across the four year time span between the SASS TQ reports and as such data from the STEM disciplines are reported in separate tables. Although the graphical separation allows for clearer depictions of the growth and changes that have occurred in each specific discipline, comparisons between the findings for each discipline also add insight into developments in STEM education nationally.

The findings from the national data gathered regarding STEM teachers' rates of interactions with ELLs shows noticeable increases in both the percentage of teachers who reported having ELLs in their service loads as well as the average number of ELLs teachers had across all of the STEM disciplines. However, the rate of growth in the percentage of teachers who reported having ELLs in their service loads differed between the disciplines. These findings as well as changes in the populations of STEM teachers are shown in tables 3-1 and 3-2. While Mathematics and Science both showed an increase in the percentage of teachers with ELLs in their service loads of more than 7\% over the four-year span, only 3.6\% more Technology teachers reported having ELLs in their service loads in the later dataset. Conversely, Technology education had the highest growth over the four-year span in the average number of ELLs teachers reported having. Interestingly, while Technology education had the lowest average number of ELLs in their service loads in the 2007-2008 dataset, in the 2011-2012 dataset they had risen to having the highest average amongst the STEM disciplines. Between both sets of data Mathematics educators had the highest percentage of teachers with ELLs in their service loads with $59.1 \%$ of Math teachers reporting having ELLs in their service loads by 2012 .

Table 3-1. Changes in STEM Teachers' Demographics Nationally

\begin{tabular}{l|c|c|c|c}
\hline & & Number of Teachers & Average Age & $\begin{array}{c}\text { Average Years of } \\
\text { Experience }\end{array}$ \\
\hline Science & $(2007-2008)$ & 210530 & 42.24 & 13.13 \\
\hline Science & $(2011-2012)$ & 226700 & 41.63 & 12.75 \\
\hline Mathematics & $(2007-2008)$ & 280480 & 41.73 & 13.18 \\
\hline Mathematics & $(2011-2012)$ & 281990 & 41.00 & 13.01 \\
\hline Technology & $(2007-2008)$ & 54570 & 45.45 & 15.07 \\
\hline Technology & $(2011-2012)$ & 50610 & 46.72 & 15.48 \\
\hline
\end{tabular}

Table 3-2. STEM Teachers' ELL Population Changes

\begin{tabular}{l|c|c|c|c}
\hline & $\begin{array}{c}\text { Percentage of } \\
\text { Teachers with ELLs } \\
\mathbf{2 0 0 7 - 0 8}\end{array}$ & $\begin{array}{c}\text { Percentage of } \\
\text { Teachers with ELLs }\end{array}$ & $\begin{array}{c}\text { Overall Mean } \\
\text { Service Load of ELLs } \\
\mathbf{2 0 1 1 - 1 2}\end{array}$ & $\begin{array}{c}\text { Overall Mean } \\
\text { Service Load of ELLs } \\
\mathbf{2 0 1 1 - 1 2}\end{array}$ \\
\hline Science & $51.0 \%$ & $58.4 \%$ & 5.72 & 7.10 \\
\hline Mathematics & $51.3 \%$ & $59.1 \%$ & 5.16 & 5.98 \\
\hline Technology & $47.2 \%$ & $50.8 \%$ & 5.08 & 7.60 \\
\hline
\end{tabular}

Findings from this study show increases in the percentage of Science teachers holding credentials in the categories of Cultural state-level Certifications, Cultural Degrees, and Linguistic Certifications. This information on Science teachers is displayed in Table 3-3. The category of Linguistic Certifications showed the most growth over the fouryear span. Surprisingly, table 3-4 displays that although the percentage of Science teachers who indicated that they had ELLs in their service loads increased over the four years, the percentage of teacher who responded that they had participated in ELL specific professional development activities in the past year decreased over the same time span. Furthermore, in both datasets over half of the Science teachers who did participate in ELL specific professional development had eight or fewer hours of such activities. It should be noted that due to the change in the total number of teachers between the datasets, both the percentage of teachers as well as the number of teachers who possess a 
credential should be examined in comparisons between years. This discrepancy is most notable in the percentage of teachers who participated in ELL specific professional development activities in the last year. For Science teachers, although the percentage of teachers who took part in ELL specific professional development decreased slightly the total number of teachers who took part increased slightly. This contrast displays that although the number of Science teachers who took part in these activities increased, the increase was not proportional to the increase in the overall number of Science teachers that took place in the four-year time span.

Table 3-3. Changes in Science Teachers' ELL Related Credentials

\begin{tabular}{|c|c|c|c|c|c}
\hline & $\begin{array}{c}\text { Mean Service } \\
\text { Load of ELLs }\end{array}$ & $\begin{array}{c}\text { Cultural } \\
\text { Certification }\end{array}$ & $\begin{array}{c}\text { Cultural Degree } \\
\text { Certification }\end{array}$ & $\begin{array}{c}\text { Linguistic } \\
\text { Cinguistic Degree }\end{array}$ \\
\hline \multirow{2}{*}{$2007-2008$} & 5.72 & $60 / 210530$ & $2710 / 210530$ & $1930 / 210530$ & $1220 / 210530$ \\
& & $0.03 \%$ & $1.29 \%$ & $0.92 \%$ & $0.58 \%$ \\
\hline \multirow{2}{*}{$2011-2012$} & \multirow{2}{*}{7.10} & $420 / 226700$ & $2960 / 226700$ & $6810 / 226700$ & $990 / 226700$ \\
& & $0.19 \%$ & $1.31 \%$ & $3.00 \%$ & $0.44 \%$ \\
\hline
\end{tabular}

Table 3-4. Changes in Science Teachers' ELL Related Professional Development

\begin{tabular}{l|c|c|c|c|c|c|c|}
\hline & $\begin{array}{c}\text { Percentage of } \\
\text { Teachers with } \\
\text { ELLs }\end{array}$ & $\begin{array}{c}\text { ELL Related } \\
\text { Professional } \\
\text { Development } \\
\text { Participation }\end{array}$ & $\begin{array}{c}\text { 8 or Less } \\
\text { Hours }\end{array}$ & $\mathbf{9 - 1 6}$ Hours & $\mathbf{1 7 - 3 2}$ Hours & $\begin{array}{c}\text { 33 or More } \\
\text { Hours }\end{array}$ \\
\hline \multirow{2}{*}{$2007-2008$} & $51.0 \%$ & $52100 / 2105302$ & $30730 / 210530$ & $8180 / 210530$ & $5950 / 210530$ & $7240 / 210530$ \\
& & $4.75 \%$ & $14.60 \%$ & $3.89 \%$ & $2.83 \%$ & $3.44 \%$ \\
\hline \multirow{2}{*}{$2011-2012$} & $58.4 \%$ & $53010 / 2267002$ & $38210 / 226700$ & $8760 / 226700$ & $3090 / 226700$ & $2950 / 226700$ \\
& & $3.38 \%$ & $16.85 \%$ & $3.86 \%$ & $1.36 \%$ & $1.30 \%$ \\
\hline
\end{tabular}

Data regarding Mathematics teachers' credentials, displayed in tables 3-5 and 3-6, showed an increase in the percentage of teachers who possessed a credential in the category of Cultural Degrees but a decrease in the prevalence of teachers with Linguistic Certifications and Linguistic Degrees. Similar to the findings regarding Science educators, a higher percentage of Mathematics educators indicated that they had ELLs in their service load in the later dataset but the percentage who had participated in ELL specific professional development activities in the last year largely stagnated over the four-year span. Although the number of Mathematics teachers that took part in these professional development activities slightly increased the percentage of the total number of Mathematics teachers that did so decreased over the four-year time span. Also common between Mathematics and Science teachers from both datasets was the fact that over half of the Mathematics teachers who participated in professional development activities specific to ELLs in the last year had eight or fewer hours of such experiences. Of notable contrast between Mathematics and Science teachers is the spike in the number of Science teachers who had a state-level certification in the category of Linguistic Certifications between the four-year span of the datasets which was not reflected in the percentage of Mathematics teachers who had such credentials.

Table 3-5. Changes in Mathematics Teachers' ELL Related Credentials

\begin{tabular}{|c|c|c|c|c|c|}
\hline & $\begin{array}{l}\text { Mean Service } \\
\text { Load of ELLs }\end{array}$ & $\begin{array}{c}\text { Cultural } \\
\text { Certification }\end{array}$ & Cultural Degree & $\begin{array}{c}\text { Linguistic } \\
\text { Certification }\end{array}$ & $\begin{array}{c}\text { Linguistic } \\
\text { Degree }\end{array}$ \\
\hline $2007-2008$ & 5.16 & $*$ & $\begin{array}{c}740 / 280480 \\
0.26 \%\end{array}$ & $\begin{array}{c}5280 / 280480 \\
1.88 \%\end{array}$ & $\begin{array}{c}2260 / 280480 \\
0.81 \%\end{array}$ \\
\hline $2011-2012$ & 5.98 & $\begin{array}{c}70 / 281990 \\
0.02 \%\end{array}$ & $\begin{array}{c}1500 / 281990 \\
0.53 \%\end{array}$ & $\begin{array}{c}5000 / 281990 \\
1.77 \%\end{array}$ & $\begin{array}{c}2010 / 281990 \\
0.71 \%\end{array}$ \\
\hline
\end{tabular}


Table 3-6. Changes in Mathematics Teachers' ELL Related Professional Development

\begin{tabular}{|c|c|c|c|c|c|c|}
\hline & $\begin{array}{c}\text { Percentage of } \\
\text { Teachers with } \\
\text { ELLs }\end{array}$ & $\begin{array}{l}\text { ELL Related } \\
\text { Professional } \\
\text { Development } \\
\text { Participation }\end{array}$ & $\begin{array}{l}8 \text { or Less } \\
\text { Hours }\end{array}$ & 9-16 Hours & 17-32 Hours & $\begin{array}{c}33 \text { or More } \\
\text { Hours }\end{array}$ \\
\hline $2007-2008$ & $51.3 \%$ & $\begin{array}{c}69690 / 280480 \\
24.85 \%\end{array}$ & $\begin{array}{c}42650 / 280480 \\
15.21 \%\end{array}$ & $\begin{array}{c}12580 / 280480 \\
4.49 \%\end{array}$ & $\begin{array}{c}5160 / 280480 \\
1.84 \%\end{array}$ & $\begin{array}{c}9300 / 280480 \\
3.32 \%\end{array}$ \\
\hline 2011-2012 & $59.1 \%$ & $\begin{array}{c}69980 / 281990 \\
24.82 \%\end{array}$ & $\begin{array}{c}51580 / 281990 \\
18.29 \%\end{array}$ & $\begin{array}{c}11080 / 281990 \\
3.93 \%\end{array}$ & $\begin{array}{c}3640 / 281990 \\
1.29 \%\end{array}$ & $\begin{array}{c}3680 / 281990 \\
1.31 \%\end{array}$ \\
\hline
\end{tabular}

The findings of this study regarding Technology educators are summarized in tables 3-7 and 3-8. These findings show that a higher percentage of Technology educators held credentials in the categories of Cultural Degrees and Linguistic Certifications in the 2011-2012 dataset than in 2007-2008. The percentage of Technology teachers who possessed a degree in the category of Linguistic Degrees decreased slightly. Notably, the number of Technology teachers who possessed a degree in the category of Cultural Degrees increased tenfold. Although the percentage of Science and Mathematics educators that possessed a degree in the category of Cultural Degrees also increased over the four year span this increase was much greater for Technology educators. A notable finding is the fact that of the STEM disciplines Technology teachers experienced the smallest growth in the percentage of teachers who had ELLs in their service loads but were the only discipline to show growth in the percentage of teachers who had taken part in ELL specific professional development activities in the past year. It should be noted that the number of Technology teachers who took part in these activities only increased slightly, but in connection with the decline in the overall number of Technology teachers the percentage that participated was noticeably higher in the later dataset. As was the case for Science and Mathematics teachers, of the Technology educators that took part in ELL specific professional development activities in the past year the majority of teachers had eight or fewer hours of these activities.

Table 3-7. Changes in Technology Teachers' ELL Related Credentials

\begin{tabular}{l|c|c|c|c|c}
\hline & $\begin{array}{c}\text { Mean Service } \\
\text { Load of ELLs }\end{array}$ & $\begin{array}{c}\text { Cultural } \\
\text { Certification }\end{array}$ & Cultural Degree & $\begin{array}{c}\text { Linguistic } \\
\text { Certification }\end{array}$ & Linguistic Degree \\
\hline \multirow{2}{*}{$2007-2008$} & 5.08 & $0 / 54570$ & $60 / 54570$ & $330 / 54570$ & $110 / 54570$ \\
& & $0 \%$ & $0.11 \%$ & $0.60 \%$ & $0.20 \%$ \\
\hline \multirow{2}{*}{$2011-2012$} & 7.60 & $0 / 50610$ & $610 / 50610$ & $520 / 50610$ & $80 / 50610$ \\
& & $0 \%$ & $1.21 \%$ & $1.03 \%$ & $0.16 \%$ \\
\hline
\end{tabular}

Table 3-8. Changes in Technology Teachers' ELL Related Professional Development

\begin{tabular}{l|c|c|c|c|c|c}
\hline & $\begin{array}{c}\text { Percentage of } \\
\text { Teachers with } \\
\text { ELLs }\end{array}$ & $\begin{array}{c}\text { ELL Related } \\
\text { Professional } \\
\text { Development } \\
\text { Participation }\end{array}$ & $\begin{array}{c}\text { 8 or Less } \\
\text { Hours }\end{array}$ & $\mathbf{9 - 1 6}$ Hours & $\mathbf{1 7 - 3 2}$ Hours & $\begin{array}{c}\text { 33 or More } \\
\text { Hours }\end{array}$ \\
\hline \multirow{2}{*}{$2007-2008$} & $47.2 \%$ & $9570 / 54570$ & $6180 / 54570$ & $2080 / 54570$ & $410 / 54570$ & $900 / 54570$ \\
& $17.54 \%$ & $11.32 \%$ & $3.81 \%$ & $0.75 \%$ & $1.65 \%$ \\
\hline \multirow{2}{*}{$2011-2012$} & $50.8 \%$ & $9600 / 50610$ & $6560 / 50610$ & $1410 / 50610$ & $1190 / 50610$ & $440 / 50610$ \\
& & $18.97 \%$ & $12.96 \%$ & $2.79 \%$ & $2.35 \%$ & $0.87 \%$ \\
\hline
\end{tabular}

Regional analysis of the number of STEM teachers, the percentage of teachers who reported having ELLs in their overall service load of students, and the mean number of ELLs teachers had in the years reported was conducted and reported in tables 3-9, 3-10, and 3-11. The Northeast region was the only region to show an increase in the number of STEM teachers in all disciplines. The Midwest region was the only region to have a decrease in the total number of Science teachers, while the other regions all had growth in their total numbers of Science teachers. The number of Mathematics teachers increased in the Northeast and Midwest while decreasing in the Southern and Western regions over the same time span. The total number of Technology teachers decreased in every region except for the Northeast. The percentage of STEM teachers who indicated having ELLs in their service loads of students increased in every discipline for every region with the exception of Mathematic teachers in the Midwest. Notably, of the STEM disciplines in the Midwest, Mathematics teachers had the highest growth in the average number of ELLs in their 
service loads. Mathematics teachers had the highest growth of percentage of teachers with ELLs in their service loads in the Northeast and West regions as well. Technology teachers had the highest growth in the percentage of teachers with ELLs in their service loads in the Midwest and had the highest growth of average number of ELLs in teachers' service loads in the Western region. Comparatively, Science teachers had the highest growth in the percentage of teachers with ELLs and the highest growth in the average number of ELLs in service loads in the South.

Table 3-9. Regional Changes in Number of STEM Teachers

\begin{tabular}{l|c|c|c|c}
\hline & Northeast & Midwest & South & West \\
\hline Science 2007-08 & 41480 & 49710 & 80600 & 38730 \\
\hline Science 2011-12 & 45480 & 48810 & 91810 & 40600 \\
\hline Mathematics 2007-08 & 55320 & 54090 & 119130 & 51940 \\
\hline Mathematics 2011-12 & 56230 & 57550 & 117050 & 51170 \\
\hline Technology 2007-08 & 13050 & 15300 & 17540 & 8690 \\
\hline Technology 2011-12 & 13950 & 11580 & 16930 & 8150 \\
\hline
\end{tabular}

Table 3-10. Regional Changes in the Percentage of STEM Teachers' serving ELLs

\begin{tabular}{l|c|c|c|c}
\hline & Northeast & Midwest & South & West \\
\hline Science 2007-08 & $41.2 \%$ & $41.3 \%$ & $51.6 \%$ & $72.4 \%$ \\
\hline Science 2011-12 & $46.6 \%$ & $43.1 \%$ & $63.5 \%$ & $78.5 \%$ \\
\hline Mathematics 2007-08 & $42.1 \%$ & $41.3 \%$ & $52.4 \%$ & $69.1 \%$ \\
\hline Mathematics 2011-12 & $52.5 \%$ & $41.1 \%$ & $61.8 \%$ & $80.3 \%$ \\
\hline Technology 2007-08 & $41.6 \%$ & $37.0 \%$ & $48.6 \%$ & $71.0 \%$ \\
\hline Technology 2011-12 & $44.3 \%$ & $43.1 \%$ & $50.6 \%$ & $73.3 \%$ \\
\hline
\end{tabular}

Table 3-11. Regional Changes in STEM Teachers' Average Number of ELLs

\begin{tabular}{l|c|c|c|c}
\hline & Northeast & Midwest & South & West \\
\hline Science 2007-08 & 4.78 & 2.35 & 3.52 & 15.64 \\
\hline Science 2011-12 & 4.61 & 2.80 & 7.06 & 15.15 \\
\hline Mathematics 2007-08 & 3.80 & 1.94 & 4.41 & 11.68 \\
\hline Mathematics 2011-12 & 4.24 & 3.13 & 4.55 & 14.35 \\
\hline Technology 2007-08 & 2.31 & 2.66 & 5.87 & 11.88 \\
\hline Technology 2011-12 & 5.32 & 3.35 & 7.01 & 18.78 \\
\hline
\end{tabular}

\section{DISCUSSION}

The population of English Language Learners in the United States K-12 education system has been growing (Calderón et al., 2011) and is projected to continue increasing over the upcoming decades (Thomas \& Collier, 2001). This growth as well as the current level of ELL inclusion in the K-12 system has led to increasing national focus on this group of learners (Molle, 2013; NCES, 2016). Areas in the United States that have not traditionally had large ELL populations but are now encountering upsurges in their populations of ELLs in schools are increasing focus on the unique needs of this population of students (Cheung, \& Slavin, 2012; Pereira, \& de Oliveira, 2015). Of particular concern is the need for teachers outside of specialized linguistic courses to adapt instructional methods to better fit the unique needs of ELLs in their classes (Samson, \& Collins, 2012). Although research indicates that educational reforms are falling short in adapting to the growing populations of ELLs nationally (August et al., 2009; Ballantyne et al., 2007; Lee, 2005; Menken, \& Antunez, 2001) largescale investigations of the nature of teachers' preparedness are largely absent from the literature on this topic. Concurrently, there is an increasing national emphasis on the utility of STEM education in an increasingly technology-laden society and workforce (Bybee, 2010; Marrero et al., 2014). The intersection of STEM teachers and ELLs is of particular interest due to the achievement gap between ELLs and their peers in these subjects (DelliCarpini \& Alonso, 2014). As such, this exploratory study investigated the preparedness of STEM educators to meet the needs of ELLs through analysis of teachers' credentials and ELL specific professional development participation nationally. 
This study utilized data from the 2007-2008 and 2011-2012 SASS TQ datasets to analyze changes in STEM teachers' credentialing in subjects that relate to ELLs, participation in ELL specific professional development activities, and the rates of ELL participation in their overall service loads of students. Regional analysis of ELL participation in the service loads of STEM teachers was also conducted to examine how the ELL populations have grown at different rates between the regions of the United States and the varying STEM disciplines. National analysis showed that for all of the STEM disciplines the percentage of teachers who had ELLs in their classes increased as did the average number of ELLs STEM teachers had in their overall service loads of students. Despite these growths in ELL participation in STEM courses the rates of ELL focused professional development participation for STEM teachers largely stagnated. Although all STEM disciplines showed slight increases in the amount of teachers who participated in these professional development activities, for Science and Math teachers these increases were not proportional to the overall growth rates of Science and Mathematics teachers which resulted in a slight decrease in the percentage of teacher who took part in these activities. Technology educators were the exception to this finding due to the decrease in the total number of Technology teachers nationally. The fact that the overall number of Technology education teachers that took part in ELL related professional development increased while the number of Technology education teachers decreased could indicate that Technology education programs that are responsive to trends in the student populations are more resilient to cuts in teacher populations.

Further investigations of STEM teachers' preparedness to meet the needs of ELLs in their courses could benefit from longitudinal analysis over a greater span of time to better examine trends in teacher credentialing, professional development participation, and the growth of ELL participation in STEM courses. Paired with national analysis of these topics more focused investigations could lend insights into how regional policies, industries, and educational initiatives have impacted STEM teachers' involvement in professional development activities and credentialing programs that focus on ELLs. Small-scale analysis could also examine factors that lead to increases in the K-12 ELL population and could be used to preemptively raise teachers' and administrators' awareness of potential ELL population growths in their areas. Corresponding with initiatives to prepare STEM teachers to meet the needs of ELLs should be investigations of research-based techniques that best utilize the unique practices of STEM education to create a learning environment that is suited to encouraging success for all students including ELLs.

\section{CONCLUSIONS}

Data across the four-year span between the SASS TQ datasets also showed that of the STEM teachers that participated in these professional development activities, the majority took part in eight or less hours of training. Although researchers have supported professional development opportunities as an effective way to bolster STEM teachers' ability to meet the needs of their ELLs (Calderón et al., 2011; Cheung, \& Slavin, 2012), the findings of this study suggest that national engagement in these opportunities has not increased in unison with the growing ELL participation in STEM disciplines. National changes in the credentialing categories of Cultural and Linguistic Degrees and Certifications, as constructed for this study, did show some noticeable growths in certain categories within specific STEM disciplines. However, the findings of this study show that for the STEM disciplines, where large growth occurred over the four-year span in in a particular category of credentialing it was not consistent between the disciplines. This could indicate a difference in reactionary credentialing between the areas and highlights the notion that these three disciplines operate in separate systems in the larger context of K-12 STEM education. Despite the national focus on STEM education as a unified concept, the lack of uniformity in the credentialing of teachers within each discipline, indicates a potential separation between the disciplines in approaches to preparing teachers to meet the needs of ELLs. Further efforts to prepare STEM teachers to meet the needs of the growing ELL population in their courses could serve a dual purpose of bringing teachers from these disciplines together as well as providing them with the necessary skills and knowledge to better meet the needs of their students.

\section{REFERENCES}

August, D., Shanahan, T., \& Escamilla, K. (2009). English language learners: Developing literacy in second-language learnersreport of the national literacy panel on language-minority children and youth. Journal of Literacy Research, 41(4), 432452. doi:10.1080/10862960903340165 
Ballantyne, K. G., Sanderman, A. R., \& Levy, J. (2007). Educating english language learners: Building teacher capacity. Washington: National Clearinghouse for English Language Acquisition. Retrieved from http://www.ncela.gwu.edu/files/uploads/3/EducatingELLsBuilding-TeacherCapacityVol3.pdf.

Breiner, J. M., Harkness, S. S., Johnson, C. C., \& Koehler, C. M. (2012). What is STEM? A discussion about conceptions of STEM in education and partnerships: What is STEM? School Science and Mathematics, 112(1), 3-11. doi:10.1111/j.1949-8594.2011.00109.x

Bybee, R. W. (2010). What is STEM education? [Editorial] Science, 329(5995), 996-996. doi:10.1126/science.1194998

Calderón, M., Slavin, R., \& Sánchez, M. (2011). Effective Instruction for English Learners. The Future of Children, 21(1), 103127.

Capraro, R. M., Capraro, M. M., \& Morgan, J. R. (2013). STEM Project-Based Learning: An Integrated Science, Technology, Engineering, and Mathematics (STEM) Approach ( $2^{\text {nd }}$ ed.). Rotterdam: Sense Publishers.

Cheung, Alan C. K. \& Slavin, R. E. (2012). Effective Reading Programs for Spanish-Dominant English Language Learners (ELLs) in the Elementary Grades: A synthesis of research. Review of Educational Research, 82(4), 351-395. doi:10.3102/0034654312465472

Daniel, S. M. (2014). Learning to Educate English Language Learners in Pre-Service Elementary Practicums. Teacher Education Quarterly, 41(2), 5. Retrieved from files.eric.ed.gov/fulltext/EJ1078517.pdf

Darling-Hammond, L. (1996) The Quiet Revolution Rethinking Teacher Development. Educational Leadership 53(6), 4-10.

DelliCarpini, M. E., \& Alonso, O. B. (2014). Teacher education that works: Preparing secondary-level math and science teachers for success with English language learners through content-based instruction. Global Education Review, 1(4), 155-178.

DiCerbo, P. A., Anstrom, K. A., Baker, L. L., \& Rivera, C. (2014). A Review of the Literature on Teaching Academic English to English Language Learners. Review of Educational Research, 84(3), 446-482. doi:10.3102/0034654314532695

Fillmore, L. W. (2014). English language learners at the crossroads of educational reform. TESOL Quarterly, 48(3), 624-632. doi:10.1002/tesq.174

García, E., Arias, M. B., Harris Murri, N. J., \& Serna, C. (2010). Developing responsive teachers: A challenge for a demographic reality. Journal of Teacher Education, 61(1-2), 132-142. doi:10.1177/0022487109347878

Honigsfeld, A., \& Dunn, R. (2009). Learning-style responsive approaches for teaching typically performing and at-risk adolescents. The Clearing House: A Journal of Educational Strategies, Issues and Ideas, 82(5), 220. doi:10.3200/TCHS.82.5.220-224

Hopstock, P., Bucaro, B., Fleischman, H., Zehler, A., Eu, H. (1993). Descriptive Study of Services to Limited English Proficient Students. Volume 2: Survey Results. Development Associates, Inc., Arlington, VA. Retrieved from: http://files.eric.ed.gov/fulltext/ED420168.pdf

Janzen, J. (2008). Teaching English language learners in the content areas. Review of Educational Research, 78(4), 1010-1038. doi: 10.3102/0034654308325580.

Krashen, S. D. (1981). Second language acquisition and second language learning (1st ed.). Oxford; New York; Oxford University Press.

Lee, O. (2005). Science education with English language learners: Synthesis and research agenda. Review of Educational Research, 75(4), 491-530. doi:10.3102/00346543075004491

Lee, O., Quinn, H., \& Valdés, G. (2013). Science and language for English language learners in relation to next generation science standards and with implications for common core state standards for English Language Arts and Mathematics. Educational Researcher, 42(4), 223-233. doi:10.3102/0013189X13480524

Liu, K., Thurlow M., Erickson, R., Spicuzza, R., \& Heinze, K. (1997). A review of the literature on students with limited English proficiency and assessment (Minnesota Report No. 11). Minneapolis, MN: University of Minnesota, National Center on Educational Outcomes. Retrieved from http://eric.ed.gov/?id=ED415641

Marrero, M. M., Gunning, A. E., \& Germain-Williams, T. (2014). What is STEM education? [Editorial] Global Education Review, 1(4), 1-6.

Menken, K., \& Antunez, B. (2001). An overview of the preparation and certification of teachers working with limited English proficient (LEP) students. National Clearinghouse for Bilingual Education, Washington, DC. Retrieved from http://eric.ed.gov/?id=ED455231

Molle, D. (2013). Facilitating professional development for teachers of english language learners. Teaching and Teacher Education, 29(Jan), 197-207. doi:10.1016/j.tate.2012.10.002

Nadelson, L. S., Seifert, A., Moll, A. J., \& Coats, B. (2012). i-STEM summer institute: An integrated approach to teacher professional development in STEM. Journal of STEM Education: Innovations and Research, 13(2), 69-83.

National Center for Education Statistics (2015). Education and Certification Qualifications of Departmentalized Public High School-Level Teachers of Core Subjects: Evidence from the 2011/12 schools and staffing survey. Retrieved from http://nces.ed.gov/pubs2015/2015814.pdf

National Center for Educational Statistics (2014). Teacher questionnaire: Schools and staffing survey 2011-12 school year. Retrieved from https://nces.ed.gov/surveys/sass/pdf/1112/SASS4A.pdf

National Center for Education Statistics, U.S. Department of Education (2016). The condition of education 2016. Retrieved from http://nces.ed.gov/programs/coe/indicator_cgf.asp 
National Clearinghouse on English Language Acquisition. (2010). NCELA State Title III Information System. Retrieved from http://www.ncela.us/t3sis

Pereira, N., \& de Oliveira, L. C. (2015). Meeting the linguistic needs of high-potential English language learners: What teachers need to know. Teaching Exceptional Children, 47(4), 208-215. doi:10.1177/0040059915569362

Portes, A., \& Böröcz, J. (1989). Contemporary immigration: Theoretical perspectives on its determinants and modes of incorporation. The International Migration Review, 23(3), 606-630.

Portes, A., \& Rumbaut, R. G. (2001). Legacies: The story of the Immigrant Second Generation. Berkeley, CA: University of California Press.

Portes, A., \& Rumbaut, R. G. (2014). Immigrant America: A portrait (4th ed.). Berkeley and Los Angeles, California: University of California Press. doi:10.1525/j.ctt7zw0nw

Samson, J., \& Collins, B., (2012) Preparing all teachers to meet the needs of English language learners. Center for American progress. Retrieved from: files.eric.ed.gov/fulltext/ED535608.pdf

Sanders, M. (2009). STEM, STEM education, STEMmania. The Technology Teacher, 68(4), 20-26.

Schwartz, S., Unger, J., Lorenzo-Blanco, E., Des Rosiers, S., Villamar, J., Soto, D., . . Szapocznik, J. (2014). Perceived context of reception among recent Hispanic immigrants: Conceptualization, instrument development, and preliminary validation. Cultural Diversity \& Ethnic Minority Psychology, 20(1), 1-15. doi:10.1037/a0033391

Thomas, P. W. \& Collier, P. V. (2001). A national study of school effectiveness for language minority students' long-term academic achievement. Retrieved from http://www.usc.edu/dept/education/CMMR/CollierThomasComplete.pdf

Tourkin, S., Thomas, T., Swaim, N., Cox, S., Parmer, R., Jackson, B,.... \& Zhang, B. (2010). Documentation for the 2007-08 Schools and Staffing Survey (NCES 2010-332). U.S. Department of Education. Washington, DC: National Center for Education Statistics. Retrieved June 17, 2014 from http://nces.ed.gov/pubsearch

U.S. Department of Education \& U.S. Department of Justice (January 7, 2015). Ensuring English learner students can participate meaningfully and equally in educational programs. Retrieved from http://www2.ed.gov/about/offices/list/ocr/docs/dcl-factsheet-el-students-201501.pdf

Zehler, A.M., Fleischman, H.L., Hopstock, P.J., Stephenson, T.G., Pendick, M.L. \& Sapru, S. (2003). Policy Report: Summary of findings related to LEP and Sp-Ed LEP students. Washington DC: U.S. Department of Education, Office of English Language Acquisition, Language Enhancement, and Academic Achievement of Limited English Proficient Students (OELA). Retrieved from ncela.us/files/rcd/BE021199/special_ed4.pdf. 